\title{
POTENCJAŁY I BARIERY ROZWOJU MAŁYCH I ŚREDNICH MIAST NA PRZYKŁADZIE POLSKIEJ KRAJOWEJ SIECI MIAST CITTASLOW
}

\section{Abstract \\ Potential and barriers to the development of small and medium-sized towns on the example of Polish Cittaslow Network}

Small and medium-sized towns play an essential role in local development and they are a vital element of the settlement network. They are service centers and places where local economic activity concentrates. In order to strengthen the potential, counteract negative social-economic phenomena, increase economic activity and achieve common goals, the towns form associations and start co-operation. Cittaslow is one of the examples of such activities. It is an international network that implements the idea of Slow City which concentrates on the improvement in the quality of life, economic development, particular care of the environment and promotion of local products. It operates according to the sustainable development rules. The aim of the research is to classify towns which are members of Polish Cittaslow Network according to their level of development and indicate potential and barriers in the development of the selected settlement units. In the research, a range of factors such as demographic, socio-economic and spatial-functional factors were considered. The diversity research was conducted with the use of mathematical-statistical method and the taxonomy method. As a result, Cittaslow towns were classified into typological groups of various level of development. Moreover, the role of the Cittaslow network in local and regional development was discussed and barriers and potential in the development of towns which especially stand out among Polish Cittaslow Network were indicated. The results showed that Cittaslow towns are marked with a considerable diversification in the level of development and potentials and barriers to development.

Keywords: Cittaslow, small and medium-sized towns, slow life, local development, taxonomic methods

\section{Streszczenie}

Małe i średnie miasta odgrywają istotną rolę w rozwoju lokalnym i stanowią ważny element sieci osadniczej. Pełnią funkcję ośrodków usługowych oraz stanowią miejsca koncentracji ak- 
tywności gospodarczej o zasięgu przede wszystkim lokalnym. W celu wzmocnienia potencjału, wsparcia aktywności gospodarczej, przeciwdziałania negatywnym zjawiskom społeczno-gospodarczym oraz aby realizować wspólne cele, zrzeszają się w stowarzyszenia i podejmują współpracę. Jednym z przykładów jest Cittaslow (wł. Cittàslow - powolne miasto) - międzynarodowa sieć miast wdrażających ideę Slow City, koncentrująca się na poprawie jakości życia, rozwoju gospodarczym, dbałości o środowisko i promocji produktów regionalnych, działająca zgodnie z zasadami zrównoważonego rozwoju. Celem badań jest klasyfikacja miast należących do Polskiej Krajowej Sieci Miast Cittaslow pod względem poziomu ich rozwoju oraz wskazanie potencjałów i barier rozwojowych wybranych jednostek osadniczych. W badaniach uwzględniono szereg wskaźników, w tym demograficzne, społeczno-gospodarcze i przestrzenno-funkcjonalne. Badanie przeprowadzono za pomocą metod matematyczno-statystycznej oraz taksonomicznej. Rezultatem badań jest klasyfikacja miast sieci Cittaslow na grupy typologiczne o różnym poziomie rozwoju. Ponadto omówiono rolę miast sieci w rozwoju lokalnym i regionalnym oraz wskazano bariery i potencjały rozwojowe miast szczególnie wyróżniających się na tle Polskiej Krajowej Sieci Miast Cittaslow. Wyniki badań wskazują, że miasta sieci Cittaslow cechują się znacznym zróżnicowaniem pod względem poziomu rozwoju oraz istniejących potencjałów i barier rozwojowych.

Słowa kluczowe: Cittaslow, małe i średnie miasta, slow life, rozwój lokalny, metody taksonomiczne

\section{Wprowadzenie}

Współczesne trendy w kształtowaniu miast pokazują, że do rozwoju i wzmacniania istniejącego potencjału najczęściej preferowane są duże aglomeracje miejskie, pozostawiając w tyle mniejsze miejscowości. Postępująca globalizacja i szybkie tempo życia, szczególnie uwidaczniające się w dużych metropoliach, zaczęły prowadzić do wzrostu świadomości i docenienia mniejszych jednostek sieci osadniczej starających się funkcjonować zgodnie z zasadami rozwoju zrównoważonego, poszanowaniem środowiska oraz dążeniem do osiągnięcia harmonii i równowagi [Honoré, 2005]. Istotny element sieci osadniczej stanowią małe i średnie miasta. Odgrywają ważną rolę w rozwoju lokalnym m.in. przez pełnienie funkcji ośrodków usługowych bądź koncentrację działalności gospodarczych przede wszystkim o lokalnym zasięgu. Duże znaczenie w rozwoju małych i średnich miast ma minimalizacja istniejących barier i wykorzystanie potencjałów rozwojowych oraz poprawa jakości życia. Rozumiana jest ona jako zapewnienie dobrych warunków mieszkaniowych, dostępu do usług, ochrony zdrowia i edukacji, dbałość o środowisko naturalne i kulturowe, wzrost aktywności gospodarczej oraz rozwój z poszanowaniem ładu przestrzennego i zasad zrównoważonego rozwoju. W publikacjach naukowych na temat potencjału rozwojowego miast uwzględniane są zróżnicowane czynniki stanowiące bariery i potencjały rozwojowe [Nazarczuk, 2013; Męczyński i in., 2010; Parysek, 1995].

Miasta zrzeszają się w stowarzyszenia i podejmują współpracę w celu realizacji wspólnych zamierzeń. Wśród nich wymienić należy wzmocnienie istniejącego potencjału, przeciwdziałanie negatywnym zjawiskom społeczno-gospodarczym, 
wspieranie działalności gospodarczej. Jednym z przykładów jest Międzynarodowe Stowarzyszenie Miast Cittaslow (wł. Cittaslow - powolne miasto) - międzynarodowa sieć miast wdrażających ideę Slow City. Celem miast zrzeszonych w Cittaslow jest szeroko rozumiana poprawa jakości życia, rozwój gospodarczy, dbałość o środowisko i dziedzictwo kulturowe, promocja produktów regionalnych, rzemiosła oraz tradycji i zwyczajów. Działania podejmowane w miastach realizowane są zgodnie z zasadami zrównoważonego rozwoju oraz z poszanowaniem środowiska naturalnego, a istotną rolę odgrywają działania prospołeczne i proekologiczne. Powolne tempo życia, jakim kierują się miasta spod znaku ślimaka, nie stoi w opozycji do postępu technologicznego. Idea Cittaslow dotyczy głównie, choć nie wyłącznie, małych ośrodków miejskich w społeczeństwach o względnie stabilnej sytuacji ekonomicznej lub głęboko zakorzenionej tradycji samorządności. Między miastami zrzeszonymi w Międzynarodowym Stowarzyszeniu Cittaslow występują różnice zależne m.in. od sytuacji społecznej, ekonomicznej i gospodarczej kraju, lokalnych i regionalnych tradycji oraz potencjałów i barier rozwojowych. Miasta Cittaslow swój rozwój opierają na nowych technologiach oraz nowoczesnych formach zarządzania, by sprawić, że staną się dobrym miejscem do życia. Członkami międzynarodowego stowarzyszenia mogą zostać miasta liczące poniżej 50 tys. mieszkańców, realizujące cele ruchu zmierzające do poprawy jakości życia mieszkańców (procedura certyfikacyjna obejmuje liczne kryteria) [Strzelecka, 2017; Gruszecka-Tieśluk, 2013; Cittaslow International, 2018].

Ideą ruchu Cittaslow jest zapewnienie mieszkańcom dobrej jakości życia, budowanie tożsamości na podstawie indywidualnych potencjałów miast oraz docenienie walorów miast małych i średnich. Zainteresowanie tematyką Cittaslow znajduje odzwierciedlenie w licznych publikacjach naukowych [Konecka-Szydłowska, 2017; Strzelecka, 2017; Zawadzka, 2017, Zadęcka, 2017; Maćkiewicz, Konecka-Szydłowska, 2017; Blazy, 2016; Kwiatek-Sołtys, Mainet, 2015; Gruszecka-Tieśluk, 2013; Grzelak-Kostulska, Hołowiecka, 2011; Grzelak-Kostulska i in., 2011; Radstrom, 2011; Poczobut, 2010; Mayer, Knox, 2006]. Badania sieci Cittaslow obejmują różnorodne dziedziny nauki, m.in.: geografię społeczno-ekonomiczną, architekturę i urbanistykę, planowanie przestrzenne, ekonomię oraz socjologię.

Do Międzynarodowej Sieci Miast Cittaslow należy 236 miast z całego świata, z czego najwięcej znajduje się we Włoszech - 84, a następnie w Polsce. Do Polskiej Krajowej Sieci Miast Cittaslow należy 28 miast (stan na listopad 2017 roku) [Cittaslow List, 2017], w tym 20 położonych jest w północno-wschodniej części kraju, w województwie warmińsko-mazurskim (tabela 1).

Miasta zrzeszone w polskiej sieci Cittaslow to miasta małe (do 20 tys. mieszkańców) i średnie (największe liczy niespełna 25 tys. mieszkańców). Spośród wszystkich miast członkowskich tylko trzy należą do miast średnich: Prudnik, Działdowo oraz Bartoszyce. Dziewięć miast liczy poniżej 5 tys. mieszkańców (Rejowiec Fabryczny, Górowo Iławeckie, Sępopol, Bisztynek, Ryn, Reszel, Jeziorany, Pasym i Rzgów). Średnia liczba mieszkańców polskiego miasta Cittaslow to blisko 9,4 tys. Pierwsze miasta, Reszel, Biskupiec, Bisztynek i Lidzbark Warmiński, przystąpiły do międzynarodowej sieci w 2006 roku. Jako ostatnie, w 2017 roku, do stowarzyszenia włączone zostały Rzgów i Sianów [Cittaslow International, 2018]. 
Tabela 1

Miasta zrzeszone w Polskiej Krajowej Sieci Miast Cittaslow

\begin{tabular}{|l|l|}
\hline \multicolumn{1}{|c|}{ Województwo } & \multicolumn{1}{c|}{ Miasta } \\
\hline warmińsko-mazurskie & $\begin{array}{l}\text { Barczewo, Bartoszyce, Biskupiec, Działdowo, Reszel, Lidz- } \\
\text { bark, Lidzbark Warmiński, Bisztynek, Nidzica, Nowe Miasto } \\
\text { Lubawskie, Ryn, Olsztynek, Lubawa, Gołdap, Dobre Miasto, } \\
\text { Pasym, Orneta, Jeziorany, Górowo Iławeckie, Sępopol }\end{array}$ \\
\hline wielkopolskie & Murowana Goślina \\
\hline śląskie & Kalety \\
\hline opolskie & Prudnik, Głubczyce \\
\hline łódzkie & Rzgów \\
\hline lubelskie & Rejowiec Fabryczny \\
\hline zachodniopomorskie & Sianów \\
\hline pomorskie & Nowy Dwór Gdański \\
\hline
\end{tabular}

Źródło: opracowanie własne.

Celem niniejszych badań jest klasyfikacja miast należących do Polskiej Krajowej Sieci Miast Cittaslow pod względem poziomu rozwoju. Wskazano także potencjały i bariery rozwojowe jednostek osadniczych szczególnie się wyróżniających. W badaniu zarówno różnic i podobieństw między miastami, jak i wpływu położenia w stosunku do pozostałych miast członkowskich oraz na tle kraju, uwzględniono wszystkie polskie miasta należące do sieci Cittaslow. Artykuł stanowi oryginalne opracowanie, w którym dokonano oceny potencjału rozwoju miast sieci Cittaslow oraz omówiono zróżnicowanie miast zarówno pod kątem ogólnego poziomu rozwoju, jak i z uwzględnieniem poszczególnych sfer (demograficznej, społeczno-gospodarczej oraz przestrzenno-funkcjonalnej). Podsumowanie stanowi przedstawienie możliwości wynikających z przynależności do sieci. Badanie zróżnicowania przeprowadzono za pomocą metod matematyczno-statystycznych oraz taksonomicznych.

\section{Materiały i metody}

Metody taksonomiczne umożliwiają klasyfikację obszarów o podobnych cechach przez wyszczególnienie jednostek do siebie podobnych przy uwzględnieniu wszystkich badanych cech. Aby ocenić potencjał rozwoju miast sieci Cittaslow oraz zbadać ich zróżnicowanie, wykorzystano metodę taksonomii wrocławskiej. Metoda ta, oparta na teorii grafów, umożliwia kompleksową analizę badanego zjawiska oraz wyeliminowanie obserwacji mało istotnych statystycznie [Pociecha, 2008; Grabiński, 1992]. Jednostkę podstawową stanowiły miasta zrzeszone 
w Polskiej Krajowej Sieci Miast Cittaslow - gminy miejskie oraz miasta w gminach miejsko-wiejskich.

Materiały źródłowe stanowiące podstawę badań pochodzą z Banku Danych Lokalnych Głównego Urzędu Statystycznego i obejmują rok 2016 (w przypadku dynamiki zmian także 2006 rok). Istotnym kryterium była dostępność statystyczna danych - cechy, dla których niemożliwe było pozyskanie danych na poziomie NUTS 5 (z włączeniem miast w gminach miejsko-wiejskich), nie zostały uwzględnione w niniejszej publikacji. Ze względu na brak danych dla niektórych jednostek osadniczych w badaniach nie wzięto pod uwagę m.in. wskaźników określających potencjał turystyczny oraz aktywność zawodową mieszkańców.

Zebrane dane poddano obróbce statystycznej. Do badań wykorzystano wskaźniki dynamiki, natężenia oraz struktury. Wskaźniki dynamiki prezentują stosunek między liczbami, które charakteryzują określone zjawisko w różnych okresach (np. dynamika zmian liczby ludności). Wskaźnik natężenia przedstawia stosunek liczby jednostek pewnej zbiorowości do drugiej zbiorowości (np. gęstość zaludnienia). Wskaźnik struktury określa udział części jednostek danej cechy do całej liczebności cechy (np. udział terenów zainwestowanych w powierzchni miasta).

Badania przeprowadzono z uwzględnieniem 28 miast zrzeszonych w Polskiej Krajowej Sieci Miast Cittaslow. Wyjściowy zestaw danych obejmował 29 cech diagnostycznych o charakterze wskaźników w sposób pośredni i bezpośredni opisujących potencjał rozwojowy. Zmienne podzielone zostały na trzy kategorie, obejmujące wskaźniki demograficzne, społeczno-gospodarcze oraz przestrzenno-funkcjonalne. Tak zróżnicowane dane umożliwiają dokonanie szczegółowej analizy oraz wszechstronne zbadanie zjawiska. Zestaw wyjściowych cech diagnostycznych ilustruje tabela 2.

Tabela 2

Wyjściowy zestaw cech diagnostycznych tworzących bazę danych

\begin{tabular}{|c|c|}
\hline Zmienna & Nazwa zmiennej \\
\hline \multicolumn{2}{|r|}{ demograficzne } \\
\hline $\mathrm{x}_{1}$ & gęstość zaludnienia \\
\hline $\mathrm{x}_{2}$ & dynamika zmian liczby ludności w latach 2010-2016 \\
\hline $\mathrm{x}_{3}$ & przyrost naturalny na 1000 mieszkańców \\
\hline $\mathrm{x}_{4}$ & $\begin{array}{l}\text { saldo migracji na pobyt stały na } 1000 \text { mieszkańców (różnica między napływem } \\
\text { a odpływem liczby mieszkańców w określonym czasie na } 1000 \text { mieszkańców) }\end{array}$ \\
\hline $\mathrm{x}_{5}$ & wskaźnik feminizacji (liczba kobiet przypadających na 100 mężczyzn) \\
\hline $\mathrm{x}_{6}$ & udział ludności w wieku poprodukcyjnym w ogólnej liczbie ludności \\
\hline $\mathrm{x}_{7}$ & $\begin{array}{l}\text { wskaźnik obciążenia demograficznego (ludność w wieku poprodukcyjnym } \\
\text { przypadająca na } 100 \text { osób w wieku produkcyjnym) }\end{array}$ \\
\hline $\mathrm{x}_{8}$ & ludność w wieku nieprodukcyjnym na 100 osób w wieku produkcyjnym \\
\hline
\end{tabular}




\begin{tabular}{|c|c|}
\hline \multicolumn{2}{|r|}{ społeczno-gospodarcze } \\
\hline $\mathrm{x}_{9}$ & $\begin{array}{l}\text { podmioty gospodarki narodowej nowo zarejestrowane w systemie REGON na } 10000 \\
\text { mieszkańców }\end{array}$ \\
\hline $\mathrm{x}_{10}$ & $\begin{array}{l}\text { podmioty gospodarki narodowej zarejestrowane w systemie REGON na } 10000 \\
\text { mieszkańców }\end{array}$ \\
\hline $\mathrm{x}_{11}$ & $\begin{array}{l}\text { potencjał produkcyjny (liczba podmiotów gospodarki narodowej zarejestrowanych } \\
\text { w systemie REGON sekcji C* na } 10000 \text { mieszkańców) }\end{array}$ \\
\hline $\mathrm{x}_{12}$ & $\begin{array}{l}\text { podmioty gospodarki narodowej zarejestrowane w systemie REGON sekcji G, H, I, J* } \\
\text { na } 10000 \text { mieszkańców }\end{array}$ \\
\hline $\mathrm{x}_{13}$ & $\begin{array}{l}\text { podmioty gospodarki narodowej zarejestrowane w systemie REGON sekcji A* na } \\
10000 \text { mieszkańców }\end{array}$ \\
\hline $\mathrm{X}_{14}$ & $\begin{array}{l}\text { udział podmiotów sekcji } \mathrm{G}, \mathrm{H}, \mathrm{I}, \mathrm{J}^{*} \text { w ogóle podmiotów gospodarczych } \\
\text { zarejestrowanych w systemie REGON }\end{array}$ \\
\hline $\mathrm{x}_{15}$ & liczba mieszkań na 1000 mieszkańców \\
\hline $\mathrm{x}_{16}$ & przeciętna powierzchnia użytkowa mieszkania na osobę \\
\hline $\mathrm{x}_{17}$ & mieszkania oddane do użytkowania w latach 2012-2016 na 1000 mieszkańców \\
\hline $\mathrm{x}_{18}$ & księgozbiór bibliotek na 1000 mieszkańców \\
\hline $\mathrm{X}_{19}$ & liczba dzieci w przedszkolach na 100 miejsc \\
\hline $\mathrm{x}_{20}$ & liczba ludności na aptekę ogólnodostępną \\
\hline \multicolumn{2}{|r|}{ przestrzenno-funkcjonalne } \\
\hline $\mathrm{x}_{21}$ & udział terenów zainwestowanych w powierzchni ogółem \\
\hline $\mathrm{x}_{22}$ & udział terenów zieleni w powierzchni ogółem \\
\hline $\mathrm{X}_{23}$ & wskaźnik intensywności zabudowy \\
\hline $\mathrm{x}_{24}$ & $\begin{array}{l}\text { udział terenów pod wodami, gruntów leśnych oraz zadrzewionych i zakrzewionych } \\
\text { w ogólnej powierzchni }\end{array}$ \\
\hline $\mathrm{x}_{25}$ & gęstość zaludnienia na terenach zainwestowanych \\
\hline $\mathrm{x}_{26}$ & $\begin{array}{l}\text { gęstość sieci drogowej (powierzchnia terenów komunikacji drogowej do powierzchni } \\
\text { gminy) }\end{array}$ \\
\hline $\mathrm{x}_{27}$ & poziom skanalizowania (udział ludności korzystającej z sieci kanalizacyjnej) \\
\hline $\mathrm{x}_{28}$ & poziom zwodociągowania (udział ludności korzystającej z sieci wodociągowej) \\
\hline $\mathrm{X}_{29}$ & liczba mieszkańców na 1 ha terenów zieleni i gruntów leśnych \\
\hline
\end{tabular}

* A - rolnictwo, leśnictwo, łowiectwo, rybactwo; $\mathrm{C}$ - przetwórstwo przemysłowe; $\mathrm{G}$ - handel hurtowy i detaliczny, naprawa pojazdów samochodowych, włączając motocykle; $\mathrm{H}$ - transport i gospodarka magazynowa; I - działalność związana z zakwaterowaniem i usługami gastronomicznymi; J - informacja i komunikacja.

Źródło: opracowanie własne. 
Prace składały się z kilku etapów. W pierwszej kolejności wyeliminowano dane, które cechowały się niską zmiennością, co oznaczało małe zróżnicowanie badanego zjawiska. Do doboru cech diagnostycznych zastosowanych w dalszych badaniach posłużono się metodą parametryczną Hellwiga. Pozwoliła ona na uniknięcie nadmiernego wpływu cech podobnych do siebie (silnie skorelowanych) oraz wytypowanie tych zmiennych, które w istotny sposób wpływają na badane zjawisko. Na podstawie macierzy korelacji wyodrębniono zmienne centralne oraz ich zmienne satelitarne, a następnie zmienne izolowane. Ostateczny zbiór cech diagnostycznych biorących udział w dalszych badaniach utworzyły zmienne centralne i zmienne izolowane. Zaletą metody parametrycznej jest możliwość takiego doboru cech diagnostycznych, aby wyeliminować silne korelacje oraz wpływ cech, których wyniki są do siebie zbliżone. W badaniach uwzględniono te zmienne, które cechują się największym zróżnicowaniem. Przystępując do dalszych analiz, przyjęto, że wszystkie cechy mają taką samą wagę. Wszystkie analizowane zmienne powinny wpływać na badane zjawiska w ten sam sposób, w związku z czym destymulanty przekształcono na stymulanty.

Do wyznaczenia obszarów o podobnych cechach wykorzystano metodę taksonomii wrocławskiej, opierającą się na teorii grafów. Metoda ta należy do hierarchicznych metod grupowania. Umożliwia ona dokonanie wielowymiarowej analizy porównawczej, kompleksowej analizy badanego zjawiska oraz wyeliminowanie obserwacji mało istotnych pod względem statystycznym [Grabiński, 1992]. Pozwala też na uporządkowanie i klasyfikację jednostek terytorialnych, a także daje obraz zróżnicowań przestrzennych, zaś w przypadku prowadzonych badań umożliwia ocenę poziomu rozwoju. Po wyborze cech diagnostycznych uwzględnionych w badaniach metodą taksonomii wrocławskiej przystąpiono do standaryzacji zmiennych, która umożliwia sprowadzenie wszystkich cech do bezpośredniej porównywalności według wzoru:

$$
\begin{aligned}
& X=\frac{x_{i}-x_{s r}}{d} \\
& \text { gdzie: } \\
& x_{i}-\text { wartość cechy, } \\
& x_{s r}-\text { średnia wartość cechy w analizowanej próbie, } \\
& \delta \text { - odchylenie standardowe z próby. }
\end{aligned}
$$

Następnym krokiem było stworzenie macierzy odległości euklidesowych wskazującej położenie każdej zmiennej w stosunku do pozostałych. Jednostki o najmniejszych odległościach łączy się ze sobą, tworząc skupienia I rzędu, następnie II rzędu i kolejne, aż do otrzymania dendrytu spójnego. Graf ten powstaje w wyniku poszukiwania zmiennych o najmniejszej odległości, czyli najbardziej do siebie podobnych [Pociecha, 2008]. Wszystkie zmienne w dendrycie łączone są ze sobą krawędziami (wiązadłami) o różnej długości, odpowiadającymi odległościom między jednostkami [Grabiński, 1992; Frąckiewicz, Zadęcki 1973; Florek 
i in., 1951]. Podział na liczbę grup stanowi jeden z bardziej dyskusyjnych etapów badań. Poszczególne grupy typologiczne wydzielono opierając się na podziale zbioru na $k$ podzbiorów. Do wyodrębnienia grup typologicznych skupiających jednostki do siebie podobne zastosowano metodę podziału naturalnego. Uporządkowano w kolejności malejącej ciąg długości wiązadeł dendrytu i obliczono indeksy [Frąckiewicz, Zadęcki, 1973; Florek i in., 1951]:

$$
w_{i}=\frac{d_{i-1}}{d_{i}}, i=2, \ldots, m
$$

gdzie:

$a_{i}^{\prime} a_{i}^{\prime}$-długość wiązadeł.

Za $k$ przyjmuje się liczbę naturalną, dla której $w_{k}<w_{k+1}$, co umożliwia największy spadek długości połączeń w dendrycie.

\section{Wyniki}

Przeprowadzone badania umożliwiły uporządkowanie i klasyfikację jednostek tery torialnych. Przyjęto, że zbiór cech diagnostycznych będzie zawierać dane cechujące się znaczną zmiennością oraz niską wzajemną korelacją. Na podstawie uzyskanych wyników wyeliminowano cechy o niskiej zmienności. Przy wyborze cech diagnostycznych wykorzystano metodę parametryczną Hellwiga. Najsilniejsze korelacje zaobserwowano między wskaźnikami opisującymi aktywność gospodarczą - jako zmienną centralną wytypowano potencjał produkcyjny. Bardzo silne korelacje wystąpiły również między gęstością zaludnienia a gęstością sieci drogowej oraz udziałem terenów zabudowanych i zurbanizowanych.

Ostateczny zbiór obejmujący dziewięć cech diagnostycznych, które uwzględniono w badaniach i w metodzie taksonomicznej, przedstawia tabela 3. Wybrane cechy ponownie oceniono pod względem merytorycznym w celu określenia poprawności w zakresie analizowanego zjawiska. Dane te poddano standaryzacji, a następnie utworzono macierz odległości euklidesowych. Następnym etapem było utworzenie spójnego dendrytu (rysunek 1) oraz dokonanie podziału na grupy typologiczne (tabela 4) skupiające jednostki najbardziej do siebie podobne. Rozmieszczenie miast sieci Cittaslow wraz z podziałem na grupy typologiczne zostało przedstawione na mapach (rysunek 2). 
Cechy diagnostyczne uwzględnione w badaniach

\begin{tabular}{|l|l|}
\hline Zmienna & \multicolumn{1}{|c|}{ Nazwa zmiennej } \\
\hline $\mathrm{x}_{1}$ & gęstość zaludnienia \\
\hline $\mathrm{x}_{3}$ & przyrost naturalny na 1000 mieszkańców \\
\hline $\mathrm{x}_{11}$ & $\begin{array}{l}\text { potencjał produkcyjny (liczba podmiotów gospodarki narodowej zarejestrowanych } \\
\text { W wystemie REGON sekcji C na } 10 \text { 000 mieszkańców) }\end{array}$ \\
\hline $\mathrm{x}_{17}$ & mieszkania oddane do użytkowania w latach 2012-2016 na 1000 mieszkańców \\
\hline $\mathrm{x}_{18}$ & księgozbiór bibliotek na 1000 mieszkańców \\
\hline $\mathrm{x}_{20}$ & liczba ludności na aptekę ogólnodostępną \\
\hline $\mathrm{x}_{23}$ & wskaźnik intensywności zabudowy \\
\hline $\mathrm{x}_{24}$ & $\begin{array}{l}\text { udział terenów pod wodami, gruntów leśnych oraz zadrzewionych i zakrzewionych } \\
\text { W ogólnej powierzchni }\end{array}$ \\
\hline $\mathrm{x}_{29}$ & liczba mieszkańców na 1 ha terenów zieleni i gruntów leśnych \\
\hline
\end{tabular}

Źródło: opracowanie własne.

W wyniku przeprowadzonych badań wyróżniono osiem grup typologicznych (tabela 4). Tak duża liczba grup jest wynikiem znacznego zróżnicowania miast pod względem analizowanych cech. Wyniki klasyfikacji uzupełnione zostały o wyniki w sferach demograficznej, społeczno-gospodarczej i przestrzenno-funkcjonalnej z uwzględnieniem cech najbardziej wyróżniających dane jednostki.

Tabela 4

Grupy typologiczne wyróżnione za pomocą metody taksonomii wrocławskiej

\begin{tabular}{|c|l|}
\hline $\begin{array}{c}\text { Grupa } \\
\text { typologiczna }\end{array}$ & \multicolumn{1}{|c|}{ Miejscowości } \\
\hline I & Murowana Goślina \\
\hline II & Rzgów \\
\hline III & Barczewo, Lubawa, Działdowo \\
\hline IV & Sianów \\
\hline V & Kalety \\
\hline VI & $\begin{array}{l}\text { Lidzbark Warmiński, Nowe Miasto Lubawskie, Lidzbark, Bartoszyce, Prudnik, } \\
\text { Biskupiec, Ryn, Sępopol, Gołdap, Pasym }\end{array}$ \\
\hline VII & Rejowiec Fabryczny \\
\hline VIII & Górowo Iławeckie, Jeziorany, Orneta, Bisztynek \\
\hline
\end{tabular}

Źródło: opracowanie własne. 


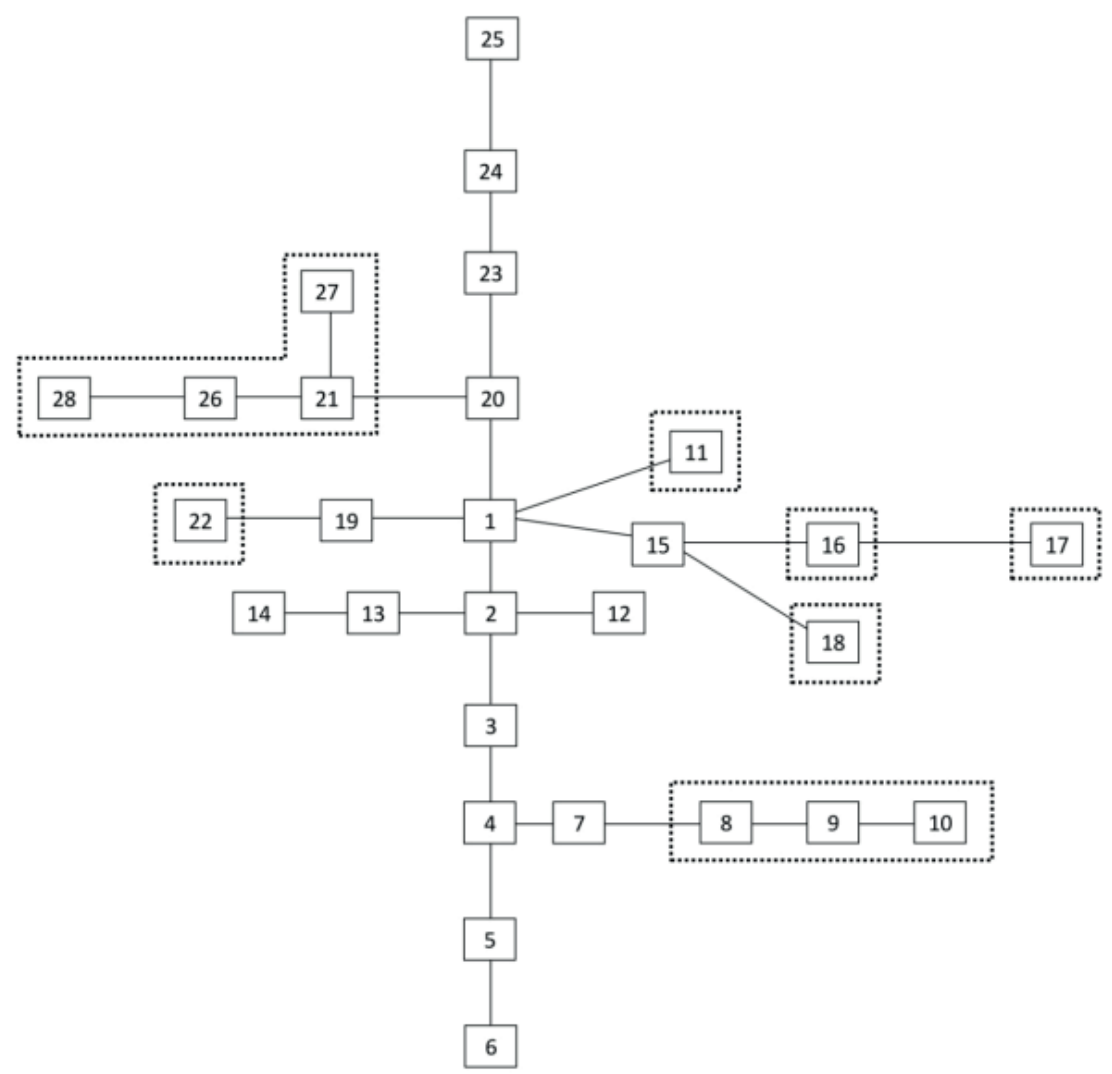

Rysunek 1. Dendryt przedstawiający powiązania między miastami oraz wydzielone grupy typologiczne

Objaśnienia: 1 - Nowe Miasto Lubawskie, 2 - Lidzbark Warmiński, 3 - Nidzica, 4 - Nowy Dwór Gdański, 5 - Dobre Miasto, 6 - Reszel, 7 - Biskupiec, 8 - Działdowo, 9 - Barczewo, 10 - Lubawa, 11 - Murowana Goślina, 12 - Prudnik, 13 - Lidzbark, 14 - Bartoszyce, 15 - Gołdap, 16 - Sianów, 17 - Rzgów, 18 - Kalety, 19 - Olsztynek, 20 - Głubczyce, 21 - Jeziorany, 22 - Rejowiec Fabryczny, 23 - Ryn, 24 - Sępopol, 25 - Pasym, 26 - Orneta, 27 - Bisztynek, 28 - Górowo Iławeckie.

Źródło: opracowanie własne.

Murowana Goślina (I grupa typologiczna) jest miastem o najwyższym poziomie rozwoju spośród wszystkich miast sieci Cittaslow. Wpływ na to wywiera położenie w aglomeracji poznańskiej i zachodzące procesy suburbanizacyjne. Murowana Goślina wyróżnia się najwyższym potencjałem demograficznym (w tym 
korzystną strukturą płci i wieku) oraz wysokim potencjałem społeczno-gospodarczym. Położenie w strefie podmiejskiej Poznania przekłada się na najwyższy przyrost naturalny wśród badanych jednostek osadniczych. Miasto charakteryzuje się wysokim poziomem przedsiębiorczości (m.in. wysoki potencjał produkcyjny, wysoka liczba podmiotów gospodarczych - w tym również usługowych - w przeliczeniu na 10 tys. mieszkańców), a także dobrą dostępnością komunikacyjną i dostępem do infrastruktury. Walory lokalizacyjne tworzą przyjazny klimat do rozwoju i inwestowania.

Rzgów, zaklasyfikowany do II grupy typologicznej, znacznie wyróżnia się na tle pozostałych miast sieci Cittaslow. Cechuje się wysokim poziomem rozwoju. W szczególności wyróżnia się wysokim potencjałem gospodarczym oraz wysokim poziomem przedsiębiorczości, w tym najwyższą liczbą podmiotów gospodarczych w przeliczeniu na 10 tys. mieszkańców, największą liczbą nowo zarejestrowanych podmiotów gospodarczych, najwyższym potencjałem produkcyjnym (ponadczterokrotnie wyższym od średniej). Bardzo wysoki udział podmiotów gospodarczych sekcji G, H, I, J (50\%) oraz największa liczba podmiotów handlowych na tle sieci Cittaslow jest wynikiem lokalizacji na terenie miasta największego w Polsce centrum handlowego wraz z infrastrukturą towarzyszącą - Centrum Handlowego Ptak. Rzgów posiada dobrze rozwinięte zaplecze handlowo-usługowe. Korzystna sytuacja gospodarcza przekłada się na dodatni przyrost rzeczywisty. Jednocześnie miasto cechuje się najniższym wskaźnikiem intensywności zabudowy i niską gęstością zaludnienia, a także najniższym udziałem terenów zieleni i jednocześnie największą liczbą ludności przypadającą na 1 ha terenów zieleni oraz lasów. Bardzo dobra sytuacja społeczno-gospodarcza jest wynikiem położenia w aglomeracji łódzkiej. Dobra dostępność komunikacyjna i lokalizacja tworzą przyjazny klimat do rozwoju inwestycji.

III grupa typologiczna obejmuje trzy miasta województwa warmińsko-mazurskiego: Działdowo, Barczewo oraz Lubawę. Miejscowości te cechują się stosunkowo wysokim poziomem rozwoju. Wszystkie wyróżniają się dodatnim przyrostem naturalnym oraz korzystną (na tle województwa warmińsko-mazurskiego) strukturą płci i wieku. Dobra sytuacja demograficzna przekłada się na dobrą sytuację na rynku nieruchomości i wysokie wartości wskaźnika intensywności zabudowy (w Działdowie najwyższy spośród analizowanych miast). W latach 2012-2016 w miastach tych oddano najwięcej mieszkań w przeliczeniu na 10 tys. mieszkańców w całej sieci Cittaslow. Wszystkie miasta cechują się bardzo niskim udziałem gruntów leśnych i gruntów pod wodami w ogólnej powierzchni. Ich potencjał turystyczny i walory przyrodniczo-krajobrazowe nie są tak wysokie, jak miast położonych we wschodniej części województwa warmińsko-mazurskiego. Poziom przedsiębiorczości jest zbliżony do średniej miast Cittaslow (z wyjątkiem Lubawy). Jednostki osadnicze cechują się dobrą dostępnością komunikacyjną. Każde z miast wyróżnia potencjał demograficzny (dodatni przyrost naturalny oraz w przypadku Barczewa również wysokie dodatnie saldo migracji). Lubawa charakteryzuje się ponadto ponadprzeciętnym poziomem przedsiębiorczości i potencjałem gospodarczym wynikającym z lokalizacji zakładów produkcyjnych, m.in. przemysłu meblarskiego. Potencjały rozwojowe miast III grupy typologicznej stanowią 
dobra dostępność komunikacyjna (w ciągu dróg krajowych) i rozwinięta funkcja usługowa dla mieszkańców miast i terenów wiejskich.

Sianów (IV grupa typologiczna) cechuje się wysokim potencjałem produkcyjnym, a także największą liczbą podmiotów gospodarczych związanych z działalnością rolniczą w przeliczeniu na 10 tys. mieszkańców (blisko dwunastokrotnie przewyższającą średnią). Niemal $45 \%$ powierzchni zajmują grunty leśne oraz grunty pod wodami. Miasto wyróżnia się niską gęstością zaludnienia oraz niską gęstością sieci drogowej. Biorąc pod uwagę potencjał demograficzny, Sianów cechuje się korzystną strukturą płci i wieku na tle pozostałych miast Cittaslow.

Do V grupy typologicznej zaklasyfikowano Kalety, wyróżniające się strukturą przestrzenno-funkcjonalną na tle pozostałych miast. Ponad $80 \%$ powierzchni miasta zajmują tereny leśne oraz grunty pod wodami (średnia dla miast Cittaslow to zaledwie 13\%). Niski stopień zurbanizowania przestrzeni miejskiej oraz najniższa gęstość zaludnienia $\left(112 \mathrm{osób} / \mathrm{km}^{2}\right)$ przekładają się na najniższą gęstość sieci drogowej oraz niską intensywność zabudowy. Jedynie 63\% mieszkańców ma przyłączenie do sieci kanalizacyjnej (najmniej spośród analizowanych jednostek osadniczych), również niski w stosunku do pozostałych miast sieci Cittaslow jest poziom zwodociągowania. Kalety cechują się przewyższającym średnią potencjałem produkcyjnym.

Najliczniejsza (VI) grupa typologiczna obejmuje 16 miast. Zgrupowane w niej są głównie miejscowości położone w województwie warmińsko-mazurskim: Lidzbark Warmiński, Nowe Miasto Lubawskie, Lidzbark, Bartoszyce, Olsztynek, Nidzica, Dobre Miasto, Reszel, Biskupiec, Sępopol, Ryn i Pasym, położone w województwie opolskim Głubczyce i Prudnik oraz w województwie pomorskim Nowy Dwór Gdański. Biorąc pod uwagę poszczególne wskaźniki w trzech analizowanych sferach, między miastami występują znaczne zróżnicowania. Najbardziej niekorzystna sytuacja demograficzna występuje w Bartoszycach oraz w miastach województwa opolskiego, Głubczycach i Prudniku, najkorzystniejsza w Gołdapi (jedyne miasto grupy z dodatnim przyrostem rzeczywistym). Do miast najbardziej wyludniających się (lata 2012-2016) należą Reszel oraz Sępopol. Największym potencjałem gospodarczym wyróżnia się Nowy Dwór Gdański. W Gołdapi oraz Lidzbarku Warmińskim potencjał rozwojowy generuje funkcja uzdrowiskowa (Gołdap - uzdrowisko, Lidzbark Warmiński - obszar ochrony uzdrowiskowej). Wysoki potencjał turystyczny cechuje przede wszystkim Ryn, Lidzbark Warmiński, Gołdap oraz Reszel. Miasta położone w sąsiedztwie Olsztyna oraz w pobliżu dróg krajowych wyróżniają się dobrą dostępnością komunikacyjną. Barierę rozwojową stanowi przygraniczne położenie, zarówno w województwie warmińsko-mazurskim, jak i opolskim.

Niekorzystna sytuacja Rejowca Fabrycznego (VII grupa typologiczna) spowodowana jest najniższym poziomem przedsiębiorczości i aktywności gospodarczej spośród analizowanych miast sieci Cittaslow, a także niekorzystną sytuacją demograficzną. Miasto cechuje się najniższym potencjałem produkcyjnym, niskim poziomem przedsiębiorczości (najmniejszą liczbą podmiotów gospodarczych, również nowo zarejestrowanych, w stosunku do liczby mieszkańców), niskim udziałem podmiotów gospodarczych związanych z usługami. Również infrastruktura 

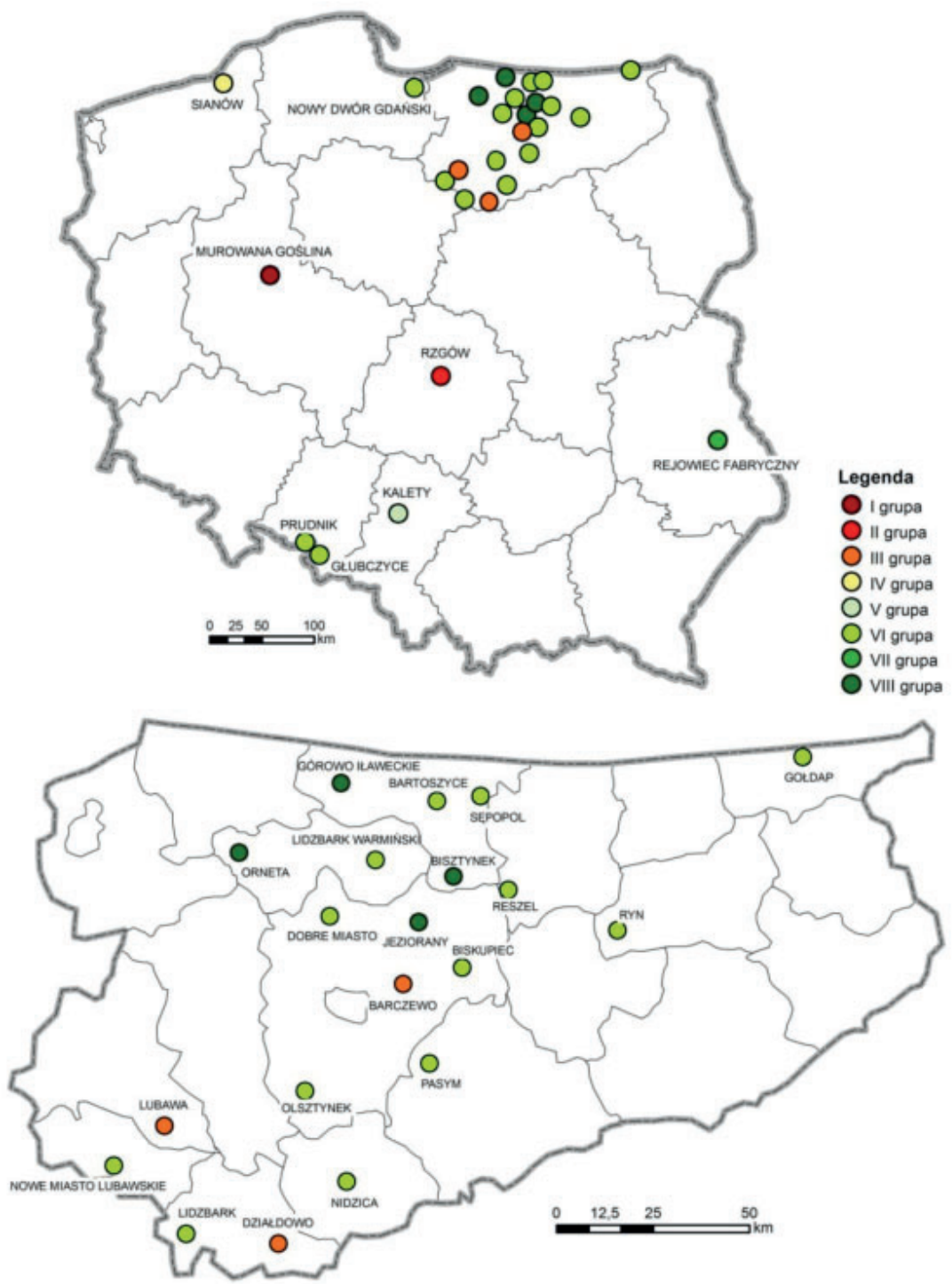

Rysunek 2. Rozmieszczenie grup typologicznych w Polsce oraz województwie warmińsko-mazurskim

Źródło: opracowanie własne. 
społeczna kształtuje się na poziomie niższym niż średni przyjęty dla analizowanych jednostek osadniczych. Czynniki te stanowią istotną barierę w rozwoju miasta.

Górowo Iławeckie, Jeziorany, Orneta oraz Bisztynek tworzą VIII grupę typologiczną. Górowo Iławeckie cechuje się najwyższym udziałem terenów zielonych i największą powierzchnią terenów zieleni i gruntów leśnych w przeliczeniu na jednego mieszkańca spośród polskich miast sieci Cittaslow. Miasta VIII grupy mają bardzo niekorzystną sytuację demograficzną, zarówno jeśli chodzi o saldo migracji, które jest ujemne, jak i przyrost naturalny (przyrost rzeczywisty przekracza -10), a także wysoką ujemną dynamikę zmian liczby ludności. Jeziorany i Bisztynek cechują się najwyższymi wartościami wskaźnika feminizacji - w obu miastach na 100 mężczyzn przypada odpowiednio 117 i 120 kobiet, co jest zjawiskiem niekorzystnym. Ponadto miejscowości te wyróżniają się stosunkowo niskim poziomem przedsiębiorczości oraz aktywności gospodarczej (wartości w okolicach średniej dla miast Cittaslow utrzymuje jedynie Orneta). Potencjał stanowi rozwój funkcji turystycznej. Otrzymanie statusu obszaru ochrony uzdrowiskowej przez gminę wiejską Górowo Iławeckie stanowi szansę na poprawę sytuacji społeczno-gospodarczej również w mieście. Bariery rozwojowe miast wynikają z niekorzystnego przygranicznego położenia fizyczno-geograficznego, złej sytuacji na rynku pracy w województwie warmińsko-mazurskim oraz silnie zaznaczającej się depopulacji.

Wyniki przeprowadzonych badań zostały przedstawione na mapach (rysunek 2). Ze względu na znaczne zagęszczenie miast w województwie warmińsko-mazurskim zostało ono wyodrębnione.

Badania z zastosowaniem proponowanych metod mogą służyć monitorowaniu rozwoju miast sieci Cittaslow, a także pomóc $\mathrm{w}$ określeniu potencjałów oraz deficytów, zarówno pod względem ogólnego poziomu rozwoju, jak i z uwzględnieniem poszczególnych sfer. Zaletą stosowanych metod badawczych jest możliwość klasyfikacji miast, a co za tym idzie, wskazania podobieństw i różnic między poszczególnymi jednostkami terytorialnymi.

\section{Podsumowanie i wnioski końcowe}

W przeprowadzonych badaniach zaobserwowano znaczne zróżnicowania w poziomie rozwoju miast sieci Cittaslow. Wysokim potencjałem rozwojowym odznaczają się miasta położone w zasięgu dużych aglomeracji miejskich, tworzące strefy podmiejskie - Murowana Goślina (strefa podmiejska Poznania) i Rzgów (strefa podmiejska Lodzi). Miasta te cechują się wysokim potencjałem demograficznym (korzystna struktura wieku i płci, dodatni przyrost rzeczywisty), społecznym, a także gospodarczym (wysoki poziom aktywności gospodarczej, dobra dostępność do dóbr i usług). Rozwój napędzany jest przez procesy suburbanizacyjne, dobre położenie komunikacyjne i oddziaływanie dużych miast. Na tle województwa warmińsko-mazurskiego pozytywnie odznaczają się Barczewo (strefa podmiejska Olsztyna) oraz Lubawa. 
Większość miast województwa warmińsko-mazurskiego oraz miasta województwa opolskiego cechują się podobieństwem pod względem stopnia rozwoju. Wyraźne różnice zaznaczają się w przypadku miast położonych w pozostałych częściach Polski. Miasta województwa warmińsko-mazurskiego, opolskiego i lubelskiego wykazują się mniejszym potencjałem rozwojowym niż miasta Cittaslow zlokalizowane w pozostałych częściach kraju. Pozwala to stwierdzić, że miasta położone w Polsce Wschodniej (warmińsko-mazurskie, lubelskie) oraz w sąsiedztwie granicy (warmińsko-mazurskie, opolskie) cechują się niższym w stosunku do pozostałych regionów Polski poziomem rozwoju, zarówno pod względem demograficznym, jak i społeczno-gospodarczym. Główne bariery rozwojowe miast województwa warmińsko-mazurskiego, opolskiego i lubelskiego stanowią położenie fizyczno-geograficzne, niekorzystna sytuacja demograficzna (depopulacja, ujemne saldo migracji, niekorzystna struktura płci i wieku), niski poziom aktywności zawodowej ludności, a także słabsza (w stosunku do pozostałych miast sieci Cittaslow) dostępność komunikacyjna. Niski potencjał demograficzny pociąga za sobą konsekwencje w postaci osłabienia aktywności gospodarczej. W przypadku miast położonych w północnej części województwa warmińsko-mazurskiego barierą ograniczającą rozwój jest również bliskie sąsiedztwo zewnętrznej granicy Unii Europejskiej (Rosja).

Na potencjał rozwojowy miast sieci Cittaslow wpływa wiele czynników wzajemnie uzupełniających się i od siebie zależnych. Istotną rolę w kształtowaniu potencjałów rozwojowych odgrywają pozycja miasta w hierarchii sieci osadniczej oraz zasięg wpływu i stopień oddziaływania jednostki osadniczej na otoczenie. Do głównych czynników wpływających na potencjał rozwojowy zaliczyć można: sytuację demograficzną (w tym przyrost naturalny, saldo migracji, strukturę płci i wieku ludności), położenie fizyczno-geograficzne, poziom aktywności gospodarczej, dostępność komunikacyjną, sytuację na rynku pracy, walory przyrodnicze i kulturowe, dostępność do dóbr i usług, stopień rozwinięcia infrastruktury technicznej i społecznej, tradycje regionu, aktywność władz samorządowych, zdolność do pozyskiwania środków na rozwój (kondycja finansowa gminy), podejmowanie współpracy, posiadanie określonej, możliwej do zrealizowania, wizji rozwoju.

Miasta należące do sieci Cittaslow wspólnie prowadzą działania promocyjne oraz edukacyjne, organizują wydarzenia kulturalne, imprezy tematyczne. Czternaście miast województwa warmińsko-mazurskiego realizuje Ponadlokalny Program Rewitalizacji. Szansą dla regionów jest rozwój funkcji turystycznej opartej na wysokiej jeziorności, lesistości i rozwuju turystyki żeglarskiej (Warmia i Mazury), dziedzictwie i krajobrazie kulturowym, możliwości wypoczynku aktywnego i biernego, czystym środowisku, spokojnym tempie życia, promocji lokalnego rzemiosła i tradycji obszaru. Najwyższym potencjałem turystycznym spośród badanych miast odznaczają się Gołdap, Lidzbark Warmiński oraz Ryn. Do największych barier rozwoju małych i średnich miast należą: konkurencja ze strony dużych miast i metropolii, niekorzystne położenie fizyczno-geograficzne, wyludnianie obszaru, zła kondycja finansowa gminy, nieodpowiednie zarządzanie miastem. 
Współpraca i przynależność do sieci i stowarzyszeń niesie ze sobą wiele korzyści i istotnie wpływa na rozwój jednostki osadniczej. Określona wizja rozwoju umożliwia realizację wyznaczonych zadań i celów. Przynależność do stowarzyszeń, podejmowanie współpracy, realizacja wspólnych działań zwiększają możliwości rozwoju miast, m.in. przez:

- możliwość zaistnienia zarówno na płaszczyźnie regionalnej, krajowej, jak i międzynarodowej;

- możliwość wymiany doświadczeń w zarządzaniu miastem i w zakresie podejmowanych działań (również z partnerami zagranicznymi);

- współpracę w ramach tworzenia i promocji inicjatywy/marki;

- określenie wizji rozwoju miast członkowskich i jako ogółu, i z uwzględnieniem indywidualnych potencjałów jednostek osadniczych;

- budowanie tożsamości mieszkańców oraz tożsamości regionalnej;

- stworzenie szansy na rozwój w szczególności w mniejszych miastach o słabszych potencjałach rozwojowych (m.in. wyludniających się);

- realizację wspólnych przedsięwzięć mających na celu poprawę poziomu życia;

- możliwość pozyskania wsparcia finansowego m.in. z funduszy europejskich.

Zaletą i marką miast sieci Cittaslow jest pochwała powolnego, spokojnego życia będąca alternatywą dla zgiełku i pośpiechu wszechobecnego w dużych miastach i metropoliach. Miasta Cittaslow stanowią silne lokalne ośrodki działające na rzecz poprawy jakości życia mieszkańców i dostrzegające możliwości rozwojowe, jakie niesie zachowanie wyjątkowego charakteru każdego z miast.

\section{Bibliografia}

Blazy R. (2016), Zagadnienia przestrzenne a postulaty i idee ruchu miast Cittaslow [w:] B. Bartosiewicz (red.), Tendencje w rozwoju gospodarczym i przestrzennym matych miast w Polsce. Trends in Economical and Spatial Development of Small Towns in Poland (s. 7-28) (Space-Society-Economy, 17), Institute of the Built Environment and Spatial Policy, Wydawnictwo Uniwersytetu Łódzkiego, Łódź.

Cittaslow International (2018), http://www.cittaslow.org [dostęp: 8.01.2018].

Cittaslow List (2017), www.cittaslow.org/sites/default/files/content/page/files/241/cittaslow list_november_2017.pdf [dostęp: 10.01.2018].

Florek K., Łukaszewicz J., Perkal J., Steinhaus H., Zubrzycki S. (1951), Taksonomia wrocławska, „Przegląd Antropologiczny”, 17, 193-211.

Frąckiewicz L., Zadęcki J. (1973), Zastosowanie taksonomii wrocławskiej do badań warunków bytu i życia ludności w regionach województwa katowickiego, „Wiadomości Statystyczne", 9, 29-33.

Grabiński T. (1992), Metody taksonometrii, Akademia Ekonomiczna w Krakowie, Kraków.

Gruszecka-Tieśluk A. (2013), Sieć Cittaslow - strategia rozwoju małych miast w Polsce?, „Studia Ekonomiczne”, 144(2), 383-393. 
Grzelak-Kostulska E., Hołowiecka B. (2011), Kreowanie wizerunku miasta a rozwój funkcji turystycznej na przykładzie wybranych miast Polskiej Sieci Cittaslow [w:] A. Rapacz (red.), Gospodarka turystyczna w regionie. Przedsiębiorstwo. Samorzad. Współpraca (s. 652-666) (Prace Naukowe Uniwersytetu Ekonomicznego we Wrocławiu, 157), Wydawnictwo Uniwersytetu Ekonomicznego, Wrocław.

Grzelak-Kostulska E., Hołowiecka B., Kwiatkowski G. (2011), Cittaslow International Network: An Example of a Globalization Idea? [w:] In The Scale of Globalization: Think Globally, Act Locally, Change Individually in the 21st Century: Conference Proceedings, University of Ostrava (s. 186-192), University of Ostrava, Ostrava.

Honoré C. (2005), In Praise of Slowless: Challenging the Cult of Speed, Harpe One, New York.

Konecka-Szydłowska B. (2017), Zróżnicowanie polskiej sieci miast Cittaslow w aspekcie społeczno-gospodarczym [w:] E. Strzelecka (red.), Alternatywne modele rozwoju miast. Sieć miast Cittaslow (s. 61-73) (Monografie), Wydawnictwo Politechniki Łódzkiej, Łódź.

Kwiatek-Sołtys A., Mainet H. (2015), Cittaslow, a Qualitative Approach to Small Towns' Local Development [w:] M. Soja, A. Zborowski (red.), Miasto w badaniach geografów, t. 2 (s. 123-135), Uniwersytet Jagielloński, Instytut Geografii i Gospodarki Przestrzennej, Kraków.

Maćkiewicz B., Konecka-Szydłowska B. (2017), Green Tourism: Attractions and Initiatives of Polish Cittaslow Cities [w:] N. Bellini, C. Pasquinelli (eds.), Tourism in the City: Towards an Integrative Agenda on Urban Tourism (s. 297-309), Springer International Publishing Switzerland, [Cham].

Mayer H., Knox L.P. (2006), Slow Cities: Sustainable Places in a Fast World, „Journal of Urban Affairs", 28(4), 321-334.

Męczyński M., Konecka-Szydłowska B., Gadziński J. (2010), Poziom rozwoju społeczno-gospodarczego i klasyfikacja matych miast Wielkopolski, Ekspertyza na zlecenie Urzędu Marszałkowskiego w Poznaniu.

Nazarczuk J.M. (2013), Potencjał rozwojowy a aktywność inwestycyjna województw i podregionów Polski, Wydawnictwo Uniwersytetu Warmińsko-Mazurskiego, Olsztyn.

Parysek J.J. (red.) (1995), Rozwój lokalny. Zagospodarowanie przestrzenne i nisze atrakcyjności gospodarczej (Studia Komitetu Przestrzennego Zagospodarowania Kraju PAN, 104), Wydawnictwo Naukowe PWN, Warszawa.

Pociecha J. (2008), Rozwój metod taksonomicznych i ich zastosowań w badaniach społeczno-ekonomicznych [w:] Statystyka społeczna. Dokonania - szanse - perspektywy, GUS, Kraków.

Poczobut J. (2010), Działania rewitalizacyjne w miasteczkach polskiej krajowej sieci miast Cittàslow, ,Zarządzanie Publiczne. Zeszyty Naukowe Instytutu Spraw Publicznych Uniwersytetu Jagiellońskiego", 1-2(9-10), 105-119.

Radstrom S. (2011), A Place-Sustaining Framework for Local Urban Identity: An Introduction and History of Cittaslow, „Italian Journal of Planning Practice”, 1(44), 90-113.

Strzelecka E. (2017), Małe miasta a nowoczesne modele rozwoju miast [w:] E. Strzelecka (red.), Alternatywne modele rozwoju miast. Sieć miast Cittaslow (s. 13-40) (Monografie), Wydawnictwo Politechniki Łódzkiej, Łódź. 
Zadęcka E. (2017), Zrównoważony rozwój małych miast w świetle warunków $i$ wymogów stowarzyszenia Cittaslow, „Zeszyty Naukowe Politechniki Częstochowskiej. Zarządzanie”, 25(2), 35-48.

Zawadzka A.K. (2017), Making Small Towns Visible in Europe: The Case of Cittaslow Network - The Strategy Based on Sustainable Development, „Transylvanian Review of Administrative Sciences" (Special Issue), 90-106. 